\title{
UPDATE ON CURRENT THERAPY OF ASTHMA
}

MAJID SADIGH, MD, Department of Internal Medicine and Infectious diseases, Saint Mary's Hospital, Waterbury, CT, USA,

Yale-affiliated, e-mail: Majid.Sadigh@yale.edu

JAIME P. MOSKOWITZ, MD, Internal Medicine Resident, Saint Mary's Hospital, Waterbury, CT, USA, Yale-affiliated,

e-mail: jaimepadavil@gmail.com

RUSTEM I. SHAYMURATOV, resident of phthisiopulmonology chair, Kazan State Medical University, 420012, Kazan,

Butlerova str. 49, e-mail: russtem@gmail.com

HE ZHANG, MD, PhD, Department of Pulmonary and Critical Medicine, Saint Mary's Hospital, Waterbury, CT, USA,

Yale-affiliated, e-mail: He.Zhang@stmh.org

ALEXANDER A. VIZEL, MD, PhD, Professor of phthisiopulmonology chair, Kazan State Medical University, 420012, Kazan,

Butlerova str. 49, e-mail: lordara@mail.ru

\begin{abstract}
Asthma is a serious health problem and one of the most common causes of morbidity and mortality worldwide. The therapy of asthma has evolved significantly during the last two decades attributing to better understanding of pathogenesis. According to asthma therapy guidelines, inhaled corticosteroids and long acting beta agonist are recommended as the corner stone of moderate to severe persistent asthma therapy. Immunotherapy is recommended as an adjuvant therapy for allergic asthma. Recently, phosphodiesterase 4 inhibitor and bronchiothermoplasty therapy are approved for asthma. We reviewed the systemic side effects of long term use of inhaled corticosteroids, safety of long acting beta ${ }_{2}$-agonist, clinical experience of immunotherapy focusing on anti-IgE therapy and specific immunotherapy, clinical evidence for use of phosphodiesterase 4 inhibitor and bronchiothermoplasty.
\end{abstract}

Key words: asthma, therapy, inhaled corticosteroids, LABA, PDE4 inhibitor, specific immunotherapy, bronchiothermoplasty.

\section{СОВРЕМЕННАЯ ТЕРАПИЯ БРОНХИАЛЬНОЙ АСТМЫ}

MAJID SADIGH, профессор внутренних болезней госпиталя Св. Марии Уотербери, шт. Коннектикут (клиника Йельского университета), e-mail: Majid.Sadigh@yale.edu

JAIME P. MOSKOWITZ, врач-резидент (внутренние болезни) госпиталя Св. Марии Уотербери, шт. Коннектикут (клиника Йельского университета), e-mail: jaimepadavi@gmail.com

РУСТЕМ ИЛЬДАРОВИЧ ШАЙМУРАТОВ, орДинатор кафедры фтизИопульМонологии ГБОУ ВПО «Казанский государственный медицинский университет» Минздравсоцразвития РФ, Казань, e-mail: russtem@gmail.com HE ZHANG, докт. мед. наук, врач отделения пульмонологии и интенсивной терапии госпиталя Св. Марии Уотербери, шт. Коннектикут (клиника Йельского университета), e-mail: He.Zhang@stmh.org

АЛЕКСАНДР АНДРЕЕВИЧ ВИЗЕЛЬ, ДоКТ. меД. наук, професСор, зав. кафеДрой фтизиопульмонологии ГОУ ВПО «Казанский государственный медицинский университет» Минздравсоцразвития РФ, Казань, 420012, ул. Бутлерова, 49, e-mail: lordara@mail.ru

Реферат. Астма - это серьезная проблема здравоохранения и одна из самых распространенных причин заболеваемости и смертности во всем мире. Благодаря прогрессу в изучении патогенеза за последние два десятка лет лечение бронхиальной астмы значительно изменилось. В соответствии с руководством по терапии астмы в качестве краеугольного камня рекомендуются ингаляционные кортикостероиды и бета ${ }_{2}$-агонисты длительного действия при степени тяжести от умеренной до тяжелой персистирующей. Иммунотерапия рекомендуется в качестве адъювантной терапии аллергической астмы. В последнее время разрешены к применению такие методы лечения, как препараты - ингибиторы фосфодиэстеразы-4 и бронхиальная термопластика. Мы рассмотрели системные побочные эффекты длительного использования ингаляционных кортикостероидов, безопасность длительного действия бета 2 -агонистов, клинический опыт иммунотерапии с акцентом на анти-IgE-терапию и специфическую иммунотерапию, данные доказательной медицины по ингибитору фоссродиэстеразы-4 и бронхиальной термопластике.

Ключевые слова: астма, лечение, ингаляционные кортикостероиды, длительно действующие бета 2 -агонисты, ингибиторы фосфодиэстеразы-4, специфическая иммунотерапия, бронхиальная термопластика.

ntroduction. Approximately $7 \%$ of Americans and

$2-5 \%$ of Russians currently have asthma $[1,2,3]$. Asthma is characterized by airflow obstruction, bronchial hyperresponsiveness, and inflammation. This inflammation causes recurrent episodes of wheezing, breathlessness, chest tightness, and coughing, which is usually worse at night and in the early morning. There are several inflammatory mediators that have been implicated in the inflammatory process, and management of these mediators can be used to treat the symptoms of asthma. The initiation of asthma therapy is based on the severity of the individual's asthma [4]. Symptoms are controlled with beta ${ }_{2}$-agonists and inhaled corticosteroids in the majority of asthmatics. However many patients with severe asthma and poorly controlled symptoms require additional forms of therapy. This review focuses on current asthma therapy as well as 
emerging novel modalities such as phosphodiesterase inhibitors, Anti-lgE therapy, specific immunotherapy, and bronchiothermoplasty.

\section{ICS: Side effects of long term inhaled corticosteroids (ICS)}

Asthma is a chronic inflammatory disease with T-helper 2 cell activation. Inhaled corticosteroids are the first-line treatment in adults and children with persistent asthma [5]. There are six different ICS that are available for clinical use: beclomethasone dipropionate, budesonide, flunisolide, fluticasone propionate, mometasone fumarate, and triamcinolone acetate. Beclomethasone disproportionate and Ciclesonide are pro-drugs which are metabolized to active metabolites. Ciclesonide is only converted to its active form in the lower respiratory tract, which helps to reduce local adverse effects such as oral thrush. Low to moderate dosage of ICS is usually adequate for asthma control. However $25-30 \%$ of asthma patients with risk of exacerbations need to take high doses to achieve control of their disease [6]

In general, ICS are very well tolerated and have much less concerns of significant side effects compared with systemic steroids. Local adverse effects due to deposition of inhaled corticorsteroids on the oropharynx and larynx include oropharyngeal candidiasis, dysphonia, and occasionally coughing from upper airway irritation. The frequency of local adverse effects depends on the dose, frequency and delivery system. For example, patients using MDI may have more complaints of dysphonia than patients using dry powder inhaler. Usually local adverse effects are easy to treat or improve. However, the systemic side effects are of concern when ICS are used for long term, in infants, children and the elderly. It is hard to assess accurately the systemic side effects of ICS because it is usually confounded by disease itself, intermittent use of oral or intravenous corticosteroids, and other co-morbidities. The majority of corticosteroids delivered by MDI are absorbed through gastrointestinal tract and inactivated in liver. About $10-20 \%$ of inhaled corticosteroids enter the systemic circulation through the lung parenchyma. With high dose ICS therapy, there are limited data supporting the presence of adrenal suppression, early onset and progression of diabetes [7]. There are no convincing data regarding effects of ICS on bone density, ocular pressure, cataract and respiratory tract infection.

The administration of exogenous corticosteroids results in a negative feedback effect on glucocorticoid receptors in the anterior pituitary gland and hypothalamus, which in turn suppresses levels of corticotropin-releasing hormone and corticotropin, respectively, and a consequent reduction in cortisol secretion from the adrenal cortex. There is no evidence of clinical significant adrenal suppression with long term use of ICS but subclinical adrenal suppression does exist based on bioassays. Measurement of urine cortisol level or early morning plasma cortisol level is used to assess adrenal insufficiency. A meta-analysis of 21 studies of urinary cortisol levels and 13 studies of suppression of $8 \mathrm{AM}$ plasma cortisol levels revealed fluticasone to exhibit significantly steeper dose-related systemic bioactivity than beclomethasone, budesonide, or triamcinolone. These effects were most apparent at doses above $0.8 \mathrm{mg} / \mathrm{d}$. [8]. On the other side, treatment with moderate and high doses of ciclesonide does not result in hypothalamus-adrenal axis suppression as compared with placebo [9].
A cohort study by Samy Suissa et al included 388,584 new users of ICS and assessed whether the use and dose of ICS increased the risk of diabetes onset and progression. Use of inhaled corticosteroids was associated with a $34 \%$ increase in the rate of diabetes and in the rate of diabetes progression. The risk was greatest with the highest inhaled corticosteroid doses, equivalent to fluticasone $1000 \mu \mathrm{g}$ per day or more [10].

Physicians prescribing ICS should be aware of the presence of subclinical adrenal suppression and increased rate and progression of diabetes associated with high dose of ICS, especially if the patients are taking a higher than recommended dosage for long term. The physician should evaluate the appropriate dosage of ICS at each visit and attempt to minimize the dosage to obtain asthma control.

\section{LABA: Safety of LABA}

There are mainly two forms of LABA available in the market, Formoterol and Salmeterol. Afroformoterol is the $\mathrm{R}, \mathrm{R}$-enantiomer of racemic formoterol. Formoterol and salmeterol have similar pharmacological properties: both are highly selective and potent beta ${ }_{2}$-agonists. Formoterol has a more rapid onset of action than salmeterol, which may make formoterol suitable for symptom relief as well as symptom prevention in the management of asthma. The duration of action of beta ${ }_{2}$-agonists depends on their diffusion microkinetics in the cell membrane lipid bilayer (plasmalemma) and in the aqueous biophase closest to the active site of the beta ${ }_{2}$-adrenoceptor. Albuterol is hydrophilic so it does not penetrate the lipid bilayer and it is quickly cleaned by microcirculation. Formoterol and Salmeterol are lipophilic, especial Salmeterol, so they bind to lipid bilayer and have persistent bronchodilator effects. Diffusion theory explains the peak effect observed in Formoterol but not in Salmeterol, and also explains there is a dose dependent response in Formoterol but not in Salmeterol [11].

In general, LABA is recommended when asthma is not controlled with low to moderate dose of ICS. In 2003, the RELIEF trial studied the safety and effectiveness of as needed formoterol compared to salbutamol. Children and adults $(n=18,124)$ were randomized to 6 months as-needed treatment with open-label formoterol $4.5 \mathrm{mg}$ Turbuhaler 1 or salbutamol $200 \mathrm{mg}$ pressurized metered dose inhaler or equivalent. This study demonstrates that formoterol asneeded has a similar safety profile to salbutamol, and its use as a reliever therapy is associated with fewer asthma symptoms and exacerbations [12]. However, post-market survey revealed there was possible increased asthma related mortality with regular use of salmeterol. This was further revealed in SMART asthma study. The SMART trial was a multicenter, double-blinded, randomized controlled observation study for 28 weeks. The study was terminated early due to the increased respiratory and asthma related mortality in asthma patient with use of salmeterol. Between 1996 and 2003, 26,355 adult asthma patients were randomized to salmeterol or salbutamol. African Americans represented $18 \%$ of the population of patients and the increased respiratory and asthma related mortality was higher in the African American population compared to Caucasians. Whether the greater risk in African Americans reflects genetic predisposition, risk associated with longacting beta ${ }_{2}$ agonist monotherapy, or health maintenance behaviors cannot be determined definitively at this time because this study was not powered or initially designed to study this [13]. Post hoc analysis revealed concurrent use of ICS might have protective effect. Only $38 \%$ of African 
American participants were on ICS concurrently but more than $50 \%$ of all study population was on ICS.

Roman Jaeschke et al did a meta-analysis studying the safety of combination of ICS and LABA. Sixty-two randomized studies and 29,000 patients were included. The study showed that in patients with asthma using ICS, LABA did not increase the risk of asthma-related hospitalizations. There were very few asthma-related deaths and intubations, and events were too infrequent to establish LABA's relative effect on these outcomes [14]. A Cochrane database review in 2010 studied the safety of adding LABA to ICS for control of asthma in children and adults. Seventy-seven randomized control studies and 21,248 participants (4625 children and 16,623 adults) with uncontrolled asthma despite current use of ICS were included. Formoterol or salmeterol was most frequently added to low-dose ICS (200 to 400 microg/ day of beclomethasone (BDP) or equivalent) in $49 \%$ of the studies. The addition of a daily LABA to ICS reduced the risk of exacerbations requiring oral steroids from $15 \%$ to $11 \%$ (28 studies, 6808 participants). The difference in the relative risk of serious adverse events with LABA was not statistically significant from that of ICS alone. Overall, the combination therapy led to greater improvement in lung function, symptoms and use of rescue beta ${ }_{2}$ agonists (although most of the results are from trials of up to 24 weeks duration). There were fewer withdrawals due to poor asthma control in this group than when using a higher dose of inhaled corticosteroids. The absence of a difference in serious adverse health events and withdrawal rates in both groups provides some indirect evidence of the safety of LABAs at usual doses as add-on therapy to ICS in adults [15].

In 2008, the FDA concluded that the monotherapy of LABAs should be banned from asthma therapy for all ages due to the concern of serious side effects. Regarding the LABA combined with ICS in a single inhaler, further safety data are needed to assess risk. LABAs should be reserved for patients whose asthma cannot be adequately managed with asthma-controller medication such as an inhaled corticosteroid [16]. In 2010, Salpeter et al did an independent meta-analysis studying the risk of LABA in combination with variable dosage of ICS. They selected randomized controlled trials in patients with asthma with a study period lasting for at least 3 months and evaluating at least one catastrophic event related to use of LABA. The catastrophic event was defined as asthma-related intubation or death. The pooled trials included 36,588 participants from 11 trials. They identified a three fold increase in asthma related intubations and deaths in those taking LABA with concomitant ICS compared with corticosteroids alone. Similar risk was noted in variable and concomittent ICS use, salmeterol and formoterol, children and adults, and fatal and nonfatal events. The safety data of monotherapy was largely from SMART study $(13,174$ out of 15,068 participants). The limitations of SMART were already discussed. The safety data of combination therapy were from three company-sponsored trials (one from GSK pooled trials regarding fluticosone/salmeterol, two from Astrazeneca sponsored trials regarding formoterol/ budesonide). In the GSK data, 8 asthma-related intubations out of 633 participants were in the salmeterol group versus 3 in placebo group. In the Astrazeneca data, 2 asthma-related deaths out of 2703 participants were reported versus none in placebo group. [17]. Due to the small number of events, it should be cautious to explain these findings.
As recommended by Asthma EPR-3, LABA is added to asthma therapy when asthma is not well controlled with low to moderate dosage of ICS. With the available data, LABA monotherapy for asthma should be rigorously avoided, and combination therapy should be mandatory only when indicated. The mechanism of $L A B A$ related severe adverse respiratory events is still unclear. Better understanding of the pharmacokinetics of LABA in asthma will help us identify the appropriate subgroup of patients benefiting from LABA therapy.

\section{Anti-IgE therapy: 10-year clinical experience with Omalizumab}

About $5-10 \%$ of asthma patient are classified as severe asthma, those who are constantly symptomatic and require frequent bronchodilator therapy with increased rate of asthma exacerbation and asthma-related mortality. More than half of these patients have positive skin test to common aeroallergens. IgE plays a central role in allergic inflammation. IgE binding to the high affinity receptor, FceRI receptors on mast cell and basophils, causes activation of mast cells and basophils, which subsequently release multiple mediators, such as Histamine, LTE C4, PGD2 and PAF. In addition, IgE can elevate the FcERI receptor level on mast cell and basophils and enhance the survival of mast cell. Omalizumab is the only approved anti-IgE therapy for allergic asthma. Omalizumab is a recombinant DNA-derived humanized monoclonal IgG $1 \mathrm{k}$ antibody binding to $\mathrm{C} \varepsilon 3$ domain of $\lg \mathrm{E}$ and forming complexes. This complex prevents IgE from binding to its receptor. Omalizumab was approved for asthma therapy by FDA in June 2003.

Omalizumab can be given subcutaneously or intravenously, but only subcutaneous injection was approved by FDA in U.S.A. The dosage of Omalizumab is calculated based on the weight and pre-therapy lgE level. It can be given every 2 to 4 weeks depending on the dosage. The bioavailability of S.C. Omalizumab is $62 \%$, and the halflife varies from 1 to 4 weeks. It is recommended for patient older than age 12 with moderate to severe persistent asthma, positive skin test or in vitro reactivity to perennial aeroallergens and non-controlled asthma with moderate to high dose ICS. In general, Omalizumab is well tolerated and there was rare anaphylaxis reaction reported (1 to 2 per 1000). There is no adequate safety data for patient younger than 12, IgE less than $30 \mathrm{IU}$ or high than $700 \mathrm{IU}$, or body weight more than $150 \mathrm{Kg}$.

Omalizumab reduces circulating levels of IgE in atopic patients to low levels commonly seen in nonatopic individuals, and protects against allergen-induced bronchoconstriction, reduces the need for short acting inhaled beta ${ }_{2}$-agonist and corticosteroids among asthmatic patients. A Cochrane review about the efficacy of omalizumab on ICS usage and asthma exacerbation was released in 2008. In this review, 14 double blinded trials and 3134 moderate to severe allergic asthmatic patients were involved. It confirmed that Omalizumab can reduce the dosage of ICS in moderate and severe asthma, but can only reduce asthma exacerbation in patient with moderate severe asthma. There was no effect on the FEV1 and morning peak flow rate although there was significant effect on quality of life. In further analysis, a significant placebo effect was identified in reducing ICS dosage. In placebo group, $56 \%$ had reduction of ICS more than $50 \%$ versus $76.7 \%$ in Omalizumab therapy group $[\mathrm{OR}=2.5,95 \% \mathrm{Cl}$, $(2.02,3.10)]$ [18]. 
Overall, multiple clinical trials proved that Omalizumab can reduce asthma exacerbation in patient with moderate severe asthma, and it is well tolerated. On the other hand, one has to realize the significant placebo effect and high cost associated with Omalizumab therapy (\$2706.54/ 4 weeks with maximal dosage of Omalizumab vs. \$213.93/ 30 days with Advair 500/50 $\mu \mathrm{g}$ ). Patient's response to anti-lgE therapy is heterogenous. About one third of the recipients showed substantial improvement, but another third showed no response. With current knowledge, it is difficult to differentiate the responders from nonresponders until after 16-week therapy. Meanwhile, anti-lgE therapy does not completely abrogate high-affinity receptor activation; has a relatively slow onset of efficacy; and due to dosing limitations, is not approved for patients with very high IgE levels, who might benefit the most from neutralization of serum IgE. Thus, approaches that inhibit high-affinity receptor activation more directly, potently, and quickly than anti-IgE therapy are promising new therapies for the treatment of asthma [19].

\section{PDE4 inhibitor: the indication and role of PDE4 inhibitor in asthma therapy}

Cyclic adenosine monophosphate (cAMP) and cyclic guanosine monophosphate (cGMP) are intracellular signalling molecules implicated in the pathophysiology of asthma. They promote smooth muscle relaxation and inhibit inflammation. A novel approach for therapeutic intervention in asthma is through regulation of the phosphodiesterase activity, which is the only cellular pathway currently known for degradation of cAMP and cGMP. Phosphodiesterase type 4 (PDE4) inhibitors increase intracellular concentrations of cAMP. Cyclic AMP acts via protein kinases, which phosphorylates ion channels and signal proteins. This in turn affects epithelial cells, mast cells, macrophages, lymphocytes and neutrophils. Cilomilast and Roflumilast are approved PDE4 inhibitors as an adjuvant therapy for COPD in Europe and USA, and only Roflumilast was approved for asthma therapy [20].

Roflumilast is approved as $500 \mu \mathrm{g}$ orally once a day for COPD and asthma. It has an $80 \%$ oral bioavailability, not affected by food intake, smoking, or diurnal dosing. Roflumilast and its major active metabolite, $\mathrm{N}$-oxide, have Tmax of $1.5 \mathrm{~h}$ and $12 \mathrm{~h}$, respectively and elimination halflives of $10 \mathrm{~h}$ and $20 \mathrm{~h}$, respectively. It does not require dose adjustment in patients with severe renal impairment. Also roflumilast and its $\mathrm{N}$-oxide do not interact with inhaled salbutamol or inhaled budesonide. The major side effects are gastrointestinal disturbances, particularly nausea and emesis as well as headache and weight loss [21].

In a double-blind, placebo-controlled, crossover study by Gauvreau et al, 25 subjects with mild allergic asthma were randomized to roflumilast $500 \mu \mathrm{g}$ or placebo, once daily for two weeks. The primary outcome was the effect of roflumilast on allergen-induced airway eosinophilia Allergen challenge was performed on Day 14, and FEV1 was measured until 7 hours post challenge. Methacholine challenge was performed on Days 1 (pre-dose), 13 (24 $\mathrm{h}$ pre-allergen), and 15 ( $24 \mathrm{~h}$ post-allergen), and sputum induction was performed on Days 1, 13, 14 (7 h postallergen), and 15. Compared to placebo, Roflumilast significantly inhibited the allergen-induced late phase response through inhibiting allergen-induced sputum eosinophil and neutrophil activation [20].

In a review article by Chung, K.F. several trials were analyzed that studied roflumilast and cilomilast. Roflumilast had a small inhibitory effect on the early response to allergen challenge in patients with mild to moderate asthma, and a bigger effect of inhibiting the late response at a dose of $500 \mu \mathrm{g}$ daily given for $7-10$ days prior to allergen. Both roflumilast and cilomilast attenuate exercise-induced bronchoconstriction. In a 3-month study of patients with asthma, there was a dose-dependent improvement in FEV1 and mean morning peak flow rates, a $16 \%$ improvement $(400 \mathrm{ml})$ in FEV1 at $500 \mu \mathrm{g} /$ day dose versus 11\% (260 ml) $100 \mu \mathrm{g} /$ day dose, which was maintained over a 12-month treatment period. In a comparative study of $500 \mu \mathrm{g} /$ day of roflumilast with inhaled beclomethasone propionate $200 \mu \mathrm{g}$ twice daily over 12 weeks, equivalent effects were observed in terms of improvement in FEV1 $(0.30 \mathrm{~L}$ for roflumilast and $0.37 \mathrm{~L}$ with beclomethasone), morning peak expiratory flows, reduction in asthma symptoms and reduction in use of rescue medications. The most frequent side-effect recorded in these studies was nausea [22]

The main criticism of all the studies to date with roflumilast in asthma is that they did not include a true randomized placebo group. Based on available data, roflumilast can be used as an adjuvant therapy to inhaled steroids for patient with mild asthma, but there is insufficient data to support the effectiveness of PDE4 inhibitors in severe persistent asthma. And there is no data to compare PDE4 inhibitors with current standard step-up therapy, such as long acting beta ${ }_{2}$-agonists, leukotriene inhibitor or theophyline. In addition, the side effects of gastrointestinal disturbances and headache may limit the use of this drug class. However, a number of strategies are currently being pursued in attempts to improve clinical efficacy and reduce side effects of PDE4 inhibitors, including delivery via the inhaled route, development of nonemetic PDE4 inhibitors, mixed PDE inhibitors, and/or antisense biologicals targeted toward PDE4.

\section{Specific Immunotherapy in allergic asthma:}

\section{the pattern of use and clinical outcome}

Specific immunotherapy (SIT) is a method of reducing sensitivity to a given allergen by repeated administration of a dose of that allergen. The primary objectives of allergenspecific immunotherapy are to decrease the symptoms triggered by allergens and to prevent recurrence of the disease in the long-term. It can also modify the immune response to allergens by inducing allergen-specific $T$ regulatory cells that reduce the late-phase response to the allergen. There is a possibility that it may alter the development of the disease, by reducing the risk of asthma onset. SIT can be administered subcuatneously or sublingually [23].

Subcutaneous immunotherapy has been found to be effective in treating asthma induced by the common allergens such as grass, mite, pet dander. This form of therapy involves the subcutaneous administration of gradually increasing quantities of the patient's relevant allergens until a dose is reached that is effective in inducing immunologic tolerance to the allergens. A Cochrane review of 88 randomized controlled trials examining the use of allergen-specific immunotherapy in asthma management confirmed its efficacy in reducing asthma symptom scores and medication requirements, and improving airway hyperresponsiveness. There was no consistent effect on lung function. Overall it would have been necessary to treat four patients $(95 \% \mathrm{Cl} 3$ to 6$)$ with immunotherapy to avoid one requiring increased medication. If 16 patients were treated with immunotherapy, one would be expected to develop 
a local adverse reaction. If nine patients were treated with immunotherapy, one would be expected to develop a systemic reaction (of any severity) [25]. Similar benefits were suggested with sublingual immunotherapy although the benefit of therapy isn't large [26]. SIT should be used in addition to bronchodilators and antihistamines for the maximum benefit. Its clinical effects are not as immediate acting and its benefits are often only appreciated in the long term. It has not been shown to be as effective as a single form of therapy.

Currently, specific immunotherapy is the only identified disease-modifying intervention for allergic disease. When used in appropriately-selected patients, allergenspecific immunotherapy is safe. A study on the frequency of systemic adverse reaction of any level of severity associated with SCIT, revealed 82 out of 693 patients $(11,3 \%)$ developed systemic adverse reaction. Of 82 patients, 69 developed during the build-up phase, and 13 in the maintenance phase. With respect to reaction time, $47(57 \%)$ of the systemic reaction were immediate (within 30 minutes respect to reaction time), and 35 (43\%) were delayed [27]. This form of therapy, however, does carry the risk of anaphylactic reactions and, therefore, should only be prescribed by physicians who are adequately trained in the treatment of allergy. Furthermore, immunotherapy should be administered only by physicians who are equipped to manage life-threatening anaphylaxis.

Using recombinant/engineered allergens, possibly modified by site-directed mutagenesis, represents an alternative approach which is directed at maintaining the immunogenicity of a vaccine while reducing the capacity to bind allergen-specific IgE. The results related to their use, hold promise that recombinant allergen-based immunotherapy will improve current immunotherapy practice and may open possibilities for prophylactic vaccination, although no clinical efficacy has been documented yet.

\section{Bronchiothermoplasty: effects on asthma control and clinical evidence}

Many of the symptoms of asthma are thought to be due to smooth muscle contraction, which then leads to bronchoconstriction. Increased airway smooth muscle mass is often found in severe asthma. Bronchial thermoplasty (BT) is performed with Alair Bronchial Thermoplasty System (Asthmatx, Inc; USA), which delivers a controlled amount of thermal energy to the airway through a specific catheter. It decreases airway muscle mass by coagulating bronchial tissue as well as bronchoconstrict response to stimulators, such as methacholine. It may improve symptomatic control and reduce asthma exacerbation [28]. Three controlled clinical trials sponsored by Asthmatx Inc, were performed to evaluate the efficacy and safety of BT.

The first multicenter prospective randomized control trial, Asthma Intervention Research trial (AIR), studied 112 patients with moderate to severe asthma, measuring a primary outcome of the change in the rate of mild exacerbations between baseline and post treatment. The subjects were between the ages of 18 to 65 and required both inhaled corticosteroids and a long acting beta ${ }_{2}$-agonist for control of asthma symptoms. In the intervention group, subjects received three BTs at three week intervals. The clinical outcomes at one year showed BT reduced the frequency of mild exacerbations at a rate equivalent to 10 exacerbations per subject per year and provided 86 additional symptom-free days per subject per year, but it did not decrease the frequency of severe exacerbation. Most frequent adverse effects associated with BT were cough, dyspnea and wheezing, and the majority of the adverse events occurred within 1 day after the procedure and resolved in an average of 7 days after the onset of the event [28].

The second multicenter prospective randomized trial, Research in Severe Asthma (RISA), assessed the safety and efficacy of BT in 32 patients with symptomatic, severe asthma. Similar to the findings in AIR trial, there was a significant increase of short-term asthma related mobidity in BT group, including seven hospitalizations [29].

In a multicenter, randomized double blind trial by Castro et al in 2009, also known as the AIR 2 trial, 288 adults were randomized to $\mathrm{BT}$ or sham control. In this trial, rather than choosing asthma exacerbation as primary outcome, the authors chose the Asthma Quality of Life Questionnaire (AQLQ). This questionnaire evaluates asthma based on symptoms, limitations of activity, emotional function and environmental factors. Subjects were required at baseline to have an AQLQ score less than 6.25 with higher scores correlating with better quality of life.

In this study, 190 subjects were randomized to the BT group and 98 were randomized to the sham control group. All subjects were scheduled to have three bronchoscopy procedures, 3 weeks apart. BT was administered to the treatment group using the Alair system. In the sham control group the subjects underwent bronchoscopy procedures that were designed to look and sound similar to the actual BT procedure. The subjects were assessed according to the AQLQ along with physical exam, review of symptoms, exacerbations and adverse effects. The subjects were followed up over a 12-month period. A greater improvement in AQLQ was noted in the treatment group comparing to the control group. On the other hand, majority of the patient in the BT group were able to guess correctly that they received the therapy, but not the sham control group. This will influence the AQLQ. There were also fewer exacerbations and ED visits associated with BT [30].

Long term safety of $\mathrm{BT}$ was recently reported by Thompson et al in 2011. Patients from the AIR1 trial were followed for adverse events post treatment study. In this study, 45 out of the 52 subjects from the treatment group were studied for 5 years while 24 out of 49 subjects of the control group were studied only for 3 years. It showed that the rate of respiratory adverse events was stable in years 2 through 5 after treatment with BT. The amount of hospitalizations and emergency room visits did not increase. There was no deterioration in FVC and FEV1. The long term benefits from BT were not studied [31].

BT was approved by Food and Drug Administration (FDA) in April 2010. The mechanism of BT has not been fully elucidated, and the long term benefits and adverse effects are still unclear. Even the limited benefit on asthma symptomatic control at one year should be balanced against the short-term adverse effects and cost of procedure. BT should be performed in an experienced center and reserved for patients who demonstrate inability to improve asthma symptoms despite the optimal use of ICS and LABA.

\section{Conclusion}

Inhaled corticosteroids and long acting beta ${ }_{2}$-agonists remain the mainstay of asthma therapy. When asthma symptoms persist despite medication compliance and good inhalational technique, other novel therapies have been shown to be promising. Anti IgE therapy can reduce asthma 
exacerbation in patients with moderate severe asthma, and it is well tolerated. However there is a significant placebo effect and high cost associated with Omalizumab therapy. Phosphodiesterase inhibitors can be used as an adjuvant therapy to inhaled steroids for patient with mild asthma, but there is insufficient data to support its effectiveness in severe persistent asthma. Immunotherapy should be used in addition to bronchodilators and antihistamines for the maximum benefit. It has not been shown to be as effective as a single form of therapy. The long term benefits and adverse effects of bronchiothermoplasty have not been fully elucidated. The limited benefit on asthma symptomatic control at one year should be balanced against adverse effects and cost.

Despite the prevalence of new and emerging therapies, a thorough history and physical, appropriate understanding of disease and compliance with therapy are more important than adding new therapy. The management of asthma is a dynamic process which can change over time. The most important key point is to educate each individual patient about their disease in order to facilitate the best management.

\section{REFERENCES}

1. The state of asthma in America: Asthma in America survey (February 9, 2009). — URL: http://www.asthmainamerica. com

2. Expert panel report 3: guidelines for the diagnosis and management of asthma. Bethesda, MD: National Heart, Lung, and Blood Institute, August 2007. (NIH publication no. 07-4051). (February 9, 2009). — URL: http://www.nhlbi.nih. gov/guidelines/asthma/asthgdln.pdf

3. Федеральная целевая программа РФ «Бронхиальная астма» на 2011--2015 годы, 2009 / Чучалин А.Г., 2000 2003, 2006; Биличенко Т.Н., 1997; Лещенко И.В., 2001; Емельянов А.В., Федосеев Г.Б., Сергеева, 2002; Федосеев Г.Б., Трофимов В.И., 2006; Княжеская Н.П., 2006.

4. Parker, M. Asthma / M. Parker // Otolaryngol. Clin. N. 2011. - Vol. 44. - P.667-684.

5. Derendorf, H. Relevance of pharmacokinetics and pharmacodynamics of inhaled corticosteroids to asthma / H. Derendorf, R. Nave, A. Drollmann [et al.] // Eur. Respir. J. - 2006. - Vol. 28, № 5. - P.1042-1050.

6. O'Sobande, P. Inhaled Corticosteroids in Asthma / P. O'Sobande, C.M. Kercsmar // Management Respiratory Care. - 2008 - Vol. 53, № 5. - P.625-634.

7. GINA Report, Global Strategy for Asthma Management and Prevention: Updated 2010. — URL: http://ginasthma.org

8. Brian, J. Lipworth Systemic Adverse Effects of Inhaled Corticosteroid Therapy A Systematic Review and Metaanalysis / J. Brian // Arch. Intern. Med. - 1999. - Vol. 159, № 9. - P.941-955.

9. Szefler, S. Ciclesonide, a Novel Inhaled Steroid, Does Not Affect Hypothalamic-Pituitary-Adrenal Axis Function in Patients With Moderate-to-Severe Persistent Asthma / S. Szefler, Sh. Rohatagi, J. Williams [et al.] // Chest. 2005. - Vol. 128, № 3. - P.1104-1114.

10. Suissa, S. Inhaled Corticosteroids and the Risks of Diabetes Onset and Progression / S. Suissa, A. Kezouh, P. Ernst // The American Journal of Medicine. — 2010. — Vol. 123, № 11. P.1001-1006.

11. Anderson, G.P. Why are long-acting beta-adrenoceptor agonists long acting? / G.P. Anderson, A. Linden, K.F. Rabe // Eur. Respir. J. — 1994. — Vol. 7, № 3. - P.569-578.

12. Pauwels, R.A. Formoterol as relief medication in asthma: a worldwide safety and effectiveness trial, on behalf of the RELIEF Study investigators / R.A. Pauwels, M.R. Sears, M. Campbell [et al.] // Eur. Respir. J. - 2003. - Vol. 22, № 5. - P.787-794.

13. Lang, D.M. The controversy over long-acting beta agonists: Examining the evidence / D.M. Lang // Cleveland Clinic Journal Of Medicine. — 2006. — Vol. 73, № 11. — P.973-992.
14. Jaeschke, $R$. The Safety of Long-Acting $\beta$-Agonists among Patients with Asthma Using Inhaled Corticosteroids Systematic Review and Metaanalysis / R. Jaeschke, P.M. O'Byrne, F. Mejza [et al.] // Am. J. Respir. Crit. Care Med. - 2008. Vol. 178, № 10. - P.1009-1016.

15. Greenstone, I.R. Combination of inhaled long-acting beta - $_{2}$ agonists and inhaled steroids versus higher dose of inhaled steroids in children and adults with persistent asthma / I.R. Greenstone, M.N. Chroinin, V. Masse [et al.] // Cochrane Database Syst. Rev. - 2010. - Vol. 4. - CD005533.

16. Chowdhury, B.A. The FDA and Safe Use of Long-Acting Beta-Agonists in the Treatment of Asthma / B.A. Chowdhury, G. Dal Pan // N. Engl. Med. J. - 2010. — Vol. 362, № 13. P.1169-1171.

17. Salpeter, S.R. Long-acting Beta-Agonists with and without Inhaled Corticosteroids and Catastrophic Asthma Events / S.R. Salpeter, A.J. Wall, N.S. Buckleyc // The American Journal of Medicine - 2010. — Vol. 123, № 4. - P.322-328.

18. Walker, S. Anti-lgE for chronic asthma in adults and children (Review) (This is a reprint of a Cochrane review, prepared and maintained by The Cochrane Collaboration and published in The Cochrane Library) / S. Walker, M. Monteil, K. Phelan [et al.]. - 2008. - Issue 4.

19. Wu, L.C. Immunoglobulin E Receptor Signaling and Asthma Published / L.C. Wu // The Journal of Biological Chemistry. 2011. - Vol. 286, № 38. - P.32891-32897.

20. Gauvreau, G.M. Roflumilast attenuates allergen-induced inflammation in mild asthmatic subjects / G.M. Gauvreau, L.-P. Boulet, C. Schmid-Wirlitsch [et al.] // Respiratory Research. - 2011. — Vol. 12, № 1. - P.140-150.

21. Lipworth, B.J. Phosphodiesterase-4 inhibitors for asthma and chronic obstructive pulmonary disease / B.J. Lipworth // Lancet . - 2005. — Vol. 365, № 9454. - P.167-175.

22. Euikyung, K. Improvement of Therapeutic Index of Phosphodiesterase Type IV Inhibitors as Anti-Asthmatics / K. Euikyung, Ch. Hyung-Ok, J. Sung-Hak [et al.] // Bioorg. Med. Chem. - 2003. — Vol. 13, № 14. - P.2355-2358.

23. Moote, W. Allergen-specific immunotherapy / W. Moote, H. Kim // Allergy, Asthma \& Clinical Immunology. - 2011. — Vol. 7, № 1. - P.5-12.

24. Bidad, K. A Review of Allergy and Allergen Specific Immunotherapy / K. Bidad, M.H. Nicknam, F. Reza // Iran J. Allergy Asthma Immunol. - 2011. - Vol. 10, № 1. P.1-9.

25. Abramson. Injection Allergen Immunotherapy for asthma / Abramson [et al.] // Cochrane Database of Systematic Reviews - 2010. - Issue 8, № CD001186. - DOI: 10.1002/14651858.CD001186.pub2

26. Calamita, Z. Efficacy of sublingual immunotherapy in asthma: systematic review of randomized clinical trials using the Cochrane Collaboration method / Z. Calamita, H. Saconato, A.B. Pela, A.N. Atallah // Allergy. — 2006. — Vol. 61, № 10. P.1162-1172.

27. Alsamarai, A.M. Systemic Adverse Reaction to Specific Immunotherapy / A.M. Alsamarai, A.H. Ahmad Alobaidi, A.M. Alwan [et al.] // J. Aller. Ther. - 2011. — Vol. 2, № 2. P.2155-2161.

28. Cox, G. Asthma Control during the Year after Bronchial Thermoplasty / G. Cox, N.C. Thompson, A.S. Rubin [et al.] // N. Engl. J. Med. — 2007. - Vol. 356, № 13. - P.1327-1337.

29. Pavord, I.D. Safety and Efficacy of Bronchial Thermoplasty in Symptomatic, Severe Asthma / I.D. Pavord, G. Cox, N.C. Thompson [et al.] // Am. J. Respir. Crit. Care Med. 2007. - Vol. 176, № 12. - P.1185-1191.

30. Castro, M. Effectiveness and Safety of Bronchial Thermoplasty in the Treatment of Severe Asthma / M. Castro, A.S. Rubin, M. Laviolette [et al.] // Am. J. Respir. Crit. Care Med. 2010. - Vol. 181, № 2. - P.116-124.

31. Thompson, N.C. Long-term (5 year) safety of bronchial thermoplasty: Asthma Intervention Research (AIR) trial / N.C. Thompson, A.S. Rubin, R.M. Niven [et al.] // BMC Pulmonary Medicine. - 2011. — Vol. 11, № 8. - P.14712476. 